\title{
Peningkatan Kapasitas Forum Anak Tangsel Mengenai Pembangunan Kota dan Komunitas Berkelanjutan
}

\author{
Rizky Hikmawan', Rizkiya Ayu Maulida ${ }^{2}$ \\ ${ }^{1}$ Program Studi Hubungan Internasional, UPN Veteran Jakarta \\ ${ }^{2}$ Program Studi Ilmu Komunikasi, UPN Veteran Jakarta \\ *e-mail: rizkyhikmawan@upnvj.ac.id ${ }^{1}$ rizkiya.maulida@upnvj.ac.id ${ }^{2}$
}

\begin{abstract}
The aim of the eleventh goal of Sustainable Development Goals (SDGs) is to create a livable city for its citizens. Therefore, this goal also intended to eliminate the problems faced by the city, such as: traffic, slum area, and the potential for natural or human made disaster. The Government of Tangsel must always prepare themselves to resolve all the problems to create a livable city. However, the responsibility for resolving existing problems does not only lie with the Government of Tangsel. The citizens are also demanded to be able to contribute to the sustainable development of the city and its communities. One of the communities in this city is Forum Anak Tangsel (Fatangsel). Therefore, we would like to facilitate a capacity building for Fatangsel to realizing their participation in developing their city and its communities through the perspective of SDGs.
\end{abstract}

Keywords: SDGs, child forum, Tangerang Selatan, capacity building

\begin{abstract}
Abstrak
Tujuan Pembangunan Berkelanjutan (TPB) poin ke-11 adalah untuk mewujudkan kota yang layak huni bagi warganya. Di balik perkembangan yang terjadi, permasalahan demi permasalahan tetap ada, seperti: kemacetan, pemukiman kumuh, dan adanya potensi bencana yang terkadang muncul dengan tibatiba. Oleh karenanya Pemerintah Kota (Pemkot) Tangsel harus senantiasa mempersiapkan diri dengan maksimal dengan membuat beragam kebijakan yang strategis yang mampu mewujudkan kota yang lebih baik sekaligus mengeliminir permasalahan-permasalahan yang ada. Namun tanggungjawab untuk menyelesaikan permasalahan yang ada tidak hanya berada di tangan Pemkot. Masyarakat juga dituntut untuk mampu berkontribusi nyata bagi pembangunan kota dan komunitas berkelanjutan, termasuk dalam hal ini adalah Forum Anak Tangsel (Fatangsel). Untuk itu, diperlukan adanya pelatihan dalam bentuk capacity building guna meningkatkan kapasitas Fatangsel dalam berpartisipasi mewujudkan kota yang mandiri, maju dan mampu mensejahterakan warganya melalui perspektif pembangunan yang berkelanjutan sebagaimana yang ada dalam SDGs.
\end{abstract}

Kata kunci: SDGs, forum anak, Tangerang Selatan, peningkatan kapasitas

\section{PENDAHULUAN}

Pada tahun 2015, Perserikatan Bangsa-Bangsa (PBB) mengesahkan suatu proyek ambisius yang dinamakan Sustainable Development Goals (SDGs). Proyek ini merupakan kelanjutan dari Millennium Development Goals (MDGs) yang berakhir tahun 2015. Terdapat 17 tujuan dan 169 target dalam SDGs yang hendak direalisasikan dalam jangka waktu 15 tahun ke depan. Artinya pada tahun 2030, tujuan-tujuan tersebut diharapkan telah terealisasi yang nantinya akan membawa kemajuan dan peningkatan kualitas hidup warga dunia. Tentu saja proyek ini harus dikawal bersama mengingat di Indonesia masih banyak permasalahan yang termasuk ke dalam 17 tujuan tersebut. Program-program turunan harus dibuat dan dilaksanakan dengan melihat kondisi masyarakat yang ada. Selain itu, dibutuhkan adanya pengawasan secara kontinu dari para stakeholder SDGs, termasuk dalam hal ini adalah masyarakat.

Di antara 17 tujuan yang ada, terdapat satu yang menarik perhatian, yakni mengenai Kota dan Pemukiman (komunitas) Berkelanjutan. Hal ini mengingat adanya beberapa peristiwa di Indonesia menyangkut kesiapan kota dalam menghadapi berbagai macam ancaman, termasuk dalam hal ini adalah bencana alam sebagaimana yang terjadi di Lombok, Palu, dan Banten. Belum lagi dengan persoalan perkotaan, seperti disparitas antara kelompok kaya dengan miskin, kemacetan, sarana publik yang buruk, dan sebagainya. Jika hal ini dibiarkan tentu dapat menganggu perkembangan dan pembangunan kota. Untuk itu, pembangunan kota dan komunitas 
harus senantiasa diupayakan dengan mengedepankan inklusivitas, keamanan, ketahanan, dan keberlanjutan. Dengan terpenuhinya hal-hal tersebut diharapkan mampu mewujudkan kota yang nyaman, aman dan layak huni sekaligus mampu meningkatkan kesejahteraan bagi warganya.

Salah satu Kota di Indonesia yang sedang merasakan pembangunan yang positif adalah Tangerang Selatan (Tangsel). Kota yang terletak di Propinsi Banten ini baru saja dinobatkan sebagai kota layak huni nomor 5 oleh Ikatan Ahli Perencanaan (IAP) Indonesia (Juliawanti, 2018). Padahal kota ini baru saja berdiri pada tahun 2008 setelah mengalami pemekaran dari Kabupaten Tangerang. Sebagai kota yang relatif muda, Tangsel juga memiliki kesempatan untuk merancang tata kota sekaligus arah pembangunan yang hendak dituju. Status sebagai daerah penyangga ibukota turut mendorong perkembangan Tangsel secara signifikan. Banyak pemukiman yang didirikan di kota ini mengingat kebutuhan properti yang terus meningkat seiring dengan perkembangan ibukota. Bahkan geliat properti yang terus berkembang menghadirkan tuntutan untuk meningkatkan fasilitas publik yang meliputi pendidikan, kesehatan, transportasi, dan sebagainya.

Hasilnya kota ini semakin hidup dengan menawarkan beragam pelayanan publik yang berkualitas. Pelayanan publik sendiri berkaitan dengan kepentingan publik dimana penyelenggara, dalam hal ini Pemda, mampu melayani masyarakat dengan kejujuran, pengelolaan anggaran yang tepat dan dapat dipertanggungjawabkan (Ardiansah \& Andrizal, 2019). Pemkot Tangsel bersama dengan pihak swasta berhasil mengembangkan pelayanan publik utama melalui keberadaan universitas maupun sekolah berkualitas, rumah sakit yang menawarkan fasilitas nomor satu, pilihan transportasi yang beragam, hingga keberadaan pusat perbelanjaan yang turut menjadi sarana hiburan warga. Kini dengan perkembangan yang ada, Tangsel juga telah mampu menawarkan diri sebagai kota perdagangan dan jasa sebagai alternatif bagi mereka yang tidak ingin terjebak pada problematika ibukota, seperti: kemacetan yang menghabiskan waktu di jalan maupun harga sewa atau beli properti usaha yang mahal. Dengan adanya perkembangan di atas, tidak mengherankan jika Tangsel telah mencanangkan dirinya sebagai Kota Pintar (smart city) pada tahun 2021.

Namun terlepas dari pencapaian yang telah diperoleh, Pemkot Tangsel beserta warga tidak boleh cepat berpuas diri. Hal ini mengingat masalah tetap ada, baik yang telah terjadi maupun masih sebatas potensi. Sebagai contoh, di beberapa titik, kemacetan masih terjadi; tuntutan pelayanan transportasi publik yang semakin baik mengingat adanya peningkatan jumlah penduduk dari tahun ke tahun; wilayah serapan air dan/atau ruang terbuka hijau yang semakin terkikis akibat adanya pembangunan pemukiman secara masif, baik oleh developer besar maupun perorangan; hingga permaslaahan-permasalahan yang menjadi tantangan bagi Tangsel ketika hendak menjadi Kota Pintar.

Selain itu, dengan semakin banyaknya warga yang tinggal di Tangsel, pemerintah juga terus memperhatikan kondisi lingkungan masyarakat agar tidak sampai membuat kota menjadi kumuh. Pemerintah sendiri telah berupaya menggalakkan program kota tanpa kumuh (Kotaku). Tujuan dari Kotaku adalah sebagai upaya memberdayakan masyarakat, Pemda, dan stakeholder lainnya agar mampu mengatasi permasalahan kumuh perkotaan (Putri, 2017). Untuk itu, upaya penyelesaian masalah yang ada sekaligus pencegahan terhadap potensi yang dapat terjadi di kemudian hari perlu dilakukan sejak dini. Upaya penyelesaian masalah ini tentu tidak hanya menjadi tugas dan tanggungjawab Pemkot semata, melainkan segenap warga, termasuk dalam hal ini adalah para pemuda.

Peran pemuda dalam upaya penyelesaian masalah menjadi krusial mengingat merekalah yang kelak akan menjadi pemimpin di Tangsel. Selain itu, idealisme dan energi mereka yang besar dapat menjadi kekuatan sendiri yang harus dimanfaatkan secara maksimal agar mampu menyelesaikan beragam masalah yang ada. Namun harus diakui bahwa para pemuda masih memiliki keterbatasan dalam hal pengetahuan dan pengalaman. Pembangunan kapasitas pemuda menjadi kunci bagi terbentuknya pemuda Tangsel yang mampu berkontribusi nyata bagi 
perkembangan kotanya. Kontribusi mereka nantinya akan menjadi kunci bagi perwujudan pembangunan kota yang berkelanjutan sebagaimana yang tercantum dalam tujuan ke-11 SDGs.

Atas dasar inilah, penulis melaksanakan Pengabdian kepada Masyarakat (PkM) dalam rangka mensosialisasikan tujuan ke-11 SDGs mengenai pembangunan kota dan pemukiman (komunitas) berkelanjutan kepada Forum Anak. Forum Anak sendiri merupakan organisasi yang menjadi wadah partisipasi bagi anak dalam perencanaan pembangunan. Komunitas ini bertugas untuk menjadi jembatan antara kepentingan anak dan pemerintah. Selain itu, forum ini juga merupakan satu-satunya organisasi anak yang resmi beroperasi dibawah pemerintahan. Fungsi Forum Anak terdiri dari 2P, yaitu Pelopor dan Pelapor. Pelopor di antara anak-anak dan Pelapor aspirasi anak kepada pengambil kebijakan. Forum Anak tersebar di seluruh provinsi di Indonesia, mulai dari tingkat nasional, provinsi, kota/kabupaten, kecamatan, kelurahan hingga RT/RW.

Salah satunya adalah Forum Anak Kota Tangerang Selatan (Fatangsel) yang terbentuk pada 2014 melalui SK Walikota Nomor: 220/Kep. 209-Huk/2017. Peran Fatangsel terbilang cukup signifikan, terutama dalam mewujudkan Tangsel sebagai Kota Layak Anak (KLA). Sejak tahun 2013-2017, Tangsel berhasil mendapatkan predikat KLA tingkat pratama dan tidak pernah naik setiap tahunnya. Fatangsel dibantu para fasilitator memetakan hal-hal apa saja yang berpotensi menghambat Tangsel naik ke peringkat di atas Pratama, yaitu: KLA Madya. Setelahnya Fatangsel melakukan advokasi ke Walikota dan OPD terkait. Selain itu, Fatangsel juga melakukan kampanye aksi ke sekolah dan fasilitas publik guna mengumpulkan suara masyarakat yang juga menginginkan Tangsel menjadi KLA. Hasilnya pun positif ketika Pemkot sepakat untuk fokus kepada KLA dan membenahi isu-isu yang selama ini menjadi faktor penghambat. Akhirnya pada tahun 2018, Tangsel berhasil memperoleh predikat KLA Madya.

Upaya mewujudkan Tangsel sebagai KLA pun masih dilakukan oleh Fatangsel. Pemetaan isu dilakukan setiap tahun dengan menampung berbagai usulan anak untuk disampaikan pada momentum Musyawarah Perencanaan Pembangunan (Musrenbang). Saat ini, Fatangsel sedang melakukan roadshow ke beberapa sekolah di Tangsel dengan menyampaikan 3 isu yang berpotensi menghambat kembali Predikat KLA, yaitu: (1) maraknya perkawinan anak; (2) menjamurnya iklan, promosi dan sponsor rokok; (3) tawuran Anak. Bagi Fatangsel, upaya meningkatkan kesadaran masyarakat, khususnya anak, penting untuk dilakukan agar menimbulkan kepekaan terhadap lingkungannya. Jika kepekaan itu hadir, maka semakin terlihat kekurangan yang bisa dikoreksi dan makin banyak pula gagasan yang bisa diusulkan.

Hanya saja, Fatangsel selama ini hanya fokus pada tiga isu di atas, tetapi belum memperhatikan aspek makro, yakni lingkungan perkotaan secara umum yang turut mempengaruhi keadaan maupun pola pikir anak. Padahal pengkondisian lingkungan agar mampu mewujudkan Tangsel sebagai KLA patut dipikirkan dan dilaksanakan. Boleh jadi ketiga masalah di atas dipengaruhi oleh lingkungan sekitar yang membentuk anak menjadi lebih mudah untuk kawin, merokok dan tawuran. Sudah seyogyanya lingkungan perkotaan dibuat agar mampu meminimalir peluang anak untuk melakukan tindakan-tindakan negatif. Untuk itu, melalui PkM ini kami bertujuan untuk memberikan penjelasan dan pemahaman kepada Fatangsel tentang pentingnya pembangunan kota dan komunitas yang berkelanjutan guna menunjang hak anak untuk dapat hidup secara layak.

\section{METODE}

Dalam PkM ini, penulis menggunakan metode peningkatan kapasitas (capacity building) yang dapat diartikan sebagai proses membangun kapasitas individu, kelompok atau organisasi yang dicerminkan melalui pengembangan kemampuan, keterampilan, potensi dan bakat serta penguasaan kompetensi sehingga memiliki kemampuan untuk bertahan sekaligus merespon perubahan yang datang (Ratnasari, Makmur, \& Ribawanto, 2013). Metode ini diartikan sebagai sebuah proses yang ditujukan untuk penguatan manajemen dan pemerintahan suatu organisasi sehingga dapat meraih tujuannya secara efektif dan memenuhi misinya (Connolly \& York, 2002). 
Untuk memenuhi misi capacity building menandakan suatu organisasi haruslah memiliki anggota staf yang memiliki pengetahuan dan skill yang dibutuhkan; memiliki sistem manajemen dan teknik yang layak; infrastruktur fisik yang pas; dan memiliki keuangan yang cukup untuk menjalankan program yang ada (Wing, 2004).

Dalam ranah pendidikan, terdapat empat tipe capacity building. Pertama, kapasitas manusia yang terdiri atas intelektualisme, seperti: pengetahuan dan skill serta keingingan yang meliputi kepentingan, kesabaran dan kegigihan. Kedua, kapasitas organisasi yang meliputi interaksi, kolaborasi, dan komunikasi antar orang di dalamnya. Ketiga, kapasitas struktural hadir secara independen dari orang-orang yang bekerja di dalam organisasi dalam bentuk kebijakan, prosedur, dan praktik. Keempat, kapasitas material yang terdiri atas sumber fiskal, material dan peralatan yang dibutuhkan untuk mencapai tujuan dan mengimplementasikan perubahan (Lammert, Johnson, \& Fiore, 2015).

Dari penjelasan di atas, peningkatan kapasitas akan dilakukan kepada anggota Fatangsel yang berusia antara 16-18 tahun dan berasal dari beberapa kecamatan di Tangsel. Setidaknya ada empat tahapan pelaksanaan yang penulis lakukan. Pertama, menjalin pertemuan dengan Fatangsel dan Badan Perencanaan Pembangunan Daerah (Bappeda) Tangsel untuk menjalin koordinasi dan komunikasi terkait kegiatan yang akan dilaksanakan. Dalam pertemuan tersebut, fasilitator mendiskusikan permasalahan anak dan perkotaan Tangsel disertai dengan konsep, metode, dan teknis pelaksanaan kegiatan yang akan dilaksanakan. Adapun keterlibatan Bappeda dalam pertemuan ini adalah mengingat statusnya sebagai badan yang bertanggungjawab menaungi aktivitas Fatangsel.

Kedua, melaksanakan kegiatan peningkatan kapasitas yang berlangsung selama dua hari yang dibagi ke dalam empat sesi. Pada sesi pertama fasilitator akan memberikan penjelasan kepada para peserta mengenai apa yang dimaksud dengan SDGs secara umum serta konsep pembangunan kota dan komunitas berkelanjutan. Selanjutnya, pada sesi kedua, peserta diminta untuk menguraikan kelebihan yang dimiliki oleh Tangsel sehingga membuat kota tersebut layak dan nyaman untuk dihuni. Di hari kedua, pada sesi ketiga, peserta diminta untuk menguraikan permasalahan-permasalahan Tangsel yang dapat menjadi penghalang bagi perwujudan pembangunan kota dan komunitas berkelanjutan di kota tersebut. Terakhir, pada sesi keempat, peserta diminta untuk mencari solusi atas permasalahan yang ada ditinjau dari potensi sumber daya yang dimiliki oleh Tangsel.

Ketiga, fasilitator akan memilih salah satu solusi yang ditawarkan oleh peserta untuk diimplementasikan secara langsung kepada masyarakat melalui suatu program tertentu. Implementasi ini juga dimaksudkan sebagai sarana evaluasi atas upaya peningkatan kapasitas yang dilakukan. Setidaknya ada dua evaluasi mendasar yang dapat dilakukan, yaitu apakah pemaparan mengenai SDGs dan pembangunan kota dan komunitas berkelanjutan telah mampu dipahami dengan baik oleh peserta; dan apakah para peserta mampu mengimplementasikan program kegiatannya dengan baik. Dari dua bentuk evaluasi inilah saran dan masukan untuk perbaikan dapat ditentukan guna membuat kegiatan peningkatan kapasitas menjadi lebih baik di masa yang akan datang.

\section{HASIL DAN PEMBAHASAN}

Kegiatan PkM dilaksanakan pada 26-27 Juni 2019 di Kantor Pemkot Tangsel. Sesi pertama, pelaksanaan PkM dimulai dengan memberikan pemahaman mendasar kepada peserta mengenai dua isu yang hendak penulis sosialisasikan. Pertama, berkenaan dengan SDGs. Adanya disparitas yang membagi dunia ke dalam binaritas antara kaya dan miskin maupun maju dan terbelakang telah mendorong PBB untuk mewujudkan kehidupan masyarakat global yang setara, baik secara ekonomi, budaya, maupun politik. SDGs merupakan kelanjutan dari program Millennium Development Goals (MDGs) yang diinisiasi oleh PBB pada tahun 2000. Berbeda dengan pendahulunya, SDGs disusun secara lebih komprehensif dan menekankan good governance dalam 
pelaksanaannya (Sachs, 2012). Hal ini dimaksudkan agar lebih banyak isu yang didorong untuk diimplementasikan di berbagai negara yang membutuhkannya. Sementara good governance dimaksudkan untuk mengoptimalkan pelaksanaan SDGs sekaligus menciptakan transparansi guna mencegah adanya praktik korupsi. Selain itu, SDGs juga diharapkan lebih mampu menciptakan engagement dengan masyarakat. Salah satu kritik yang diberikan kepada MDGs adalah mengenai partisipasi publik yang relatif rendah, baik dalam konteks keterlibatan secara langsung maupun dalam mengkampanyekan program tersebut. Dengan indikator-indikator yang lebih terukur, setiap individu diharapkan dapat berpartisipasi guna mensosialisasikan SDGs kepada masyarakat secara umum. Keterlibatan masyarakat yang lebih luas diharapkan mampu mendukung SDGs dengan lebih maksimal.

Kedua, pembangunan kota dan komunitas berkelanjutan. Perkembangan kota yang signifikan seringkali mengabaikan kelestarian lingkungan. Atas nama pembangunan, kelestarian lingkungan dikesampingkan. Padahal hal ini dapat mengganggu keseimbangan alam yang justru dapat memicu terjadinya berbagai macam bencana. Dengan semakin sempitnya lahan hijau, upaya-upaya untuk menciptakan ruang terbuka hijau menjadi lebih digiatkan. Tujuannya tidak lain adalah untuk membuat bumi tempat kita tinggal tetap terawat dan lestari. Hal ini sebenarnya telah digagas dengan adanya United Nations Conference on the Human Environment (UNCHE) tahun 1972 yang menghasilkan Deklarasi Stockholm (United Nations, 1973). Dalam perkembangan selanjutnya Deklarasi Stockholm menjadi salah satu acuan ketika Komisi Dunia untuk Lingkungan dan Pembangunan menawarkan konsep Pembangunan Berkelanjutan yang diadopsi dalam Sidang Umum PBB 1989.

Guna mewujudkan kota yang berbasiskan pembangunan berkelanjutan ada tiga tujuan yang senantiasa harus diperhatikan, yaitu: ekonomis, ekologis, dan sosial. Tujuan ekonomi menyasar pada upaya peningkatan pertumbuhan ekonomi kota yang nantinya akan mampu mengentaskan kemiskinan, pemerataan ekonomi dan meningkatkan kesejahteraan. Sementara tujuan ekologis berbicara mengenai dampak pembangunan yang harus memperhatikan integritas ekosistem. Sedangkan tujuan sosial menekankan pada partisipasi semua pihak dalam mewujudkan pemerataan sosial dengan mengedepankan integritas budaya yang dimiliki masyarakat dan kota. Dari tiga tujuan inilah dapat dipahami bahwasanya kota yang berbasiskan pembangunan berkelanjutan merupakan daerah yang mampu melindungi dan memilihara sumber daya alam di kota dan wilayah sekitarnya agar dapat dimanfaatkan secara berkelanjutan.

Di dalam SDGs, pembangunan kota dan pemukiman berkelanjutan terdapat dalam Tujuan ke-11. Di Tujuan ini kemudian diturunkan ke dalam 7 target yang hendak dicapai pada 2030, yaitu: (i) perumahan yang aman dan terjangkau; (ii) sistem transportasi yang terjangkau dan berkelanjutan; (iii) urbanisasi yang inklusif dan berkelanjutan; (iv) perlindungan atas warisan budaya dan alam; (v) mengurangi dampak bencana alam; (vi) mengurangi dampak lingkungan pada perkotaan; (vii) menyediakan akses inklusif untuk melindungi ruang hijau dan publik. Selain target-target di atas, tujuan ke-11 SDGs juga mencantumkan tiga syarat yang harus dipenuhi untuk mendukung terealisasinya tujuh target di atas. Tanpa adanya dukungan dari ketiga syarat ini dikhawatirkan akan membuat tujuh target yang diusung tidak dapat terealisasi dengan baik. Adapun ketiga syarat tersebut adalah: (i) perencanaan pembangunan yang kuat di tingkat nasional maupun regional; (ii) implementasi kebijakan untuk inklusi, efisiensi sumber daya dan pengurangan resiko bencana; (iii) mendukung negara terbelakang dalam pembangunan dan ketahanan berkelanjutan (Badan Perencanaan Pembangunan Nasional, 2017).

Tantangan yang kemudian harus dihadapi oleh pemerintah adalah mengenai bagaimana menurunkan target dan indikator yang ada pada level lokal atau pemerintah daerah. Hal ini mengingat setiap daerah memiliki karakteristik yang berbeda. Sementara di sisi lain peran dari kota dan kabupaten sangat penting guna merealisasikan SDGs. Setidaknya ada empat variabel yang dapat menjelaskan hal tersebut, yaitu: pembentukan gugus tugas untuk SDGs di tingkat daerah dan penyusunan agenda Habitat III; adanya keterlibatan nyata pemerintah kota dan daerah sebagaimana yang tercantum dalam tujuan kesebelas; paragraf nomor 45 dalam dokumen SDGs menyatakan bahwa negara anggota PBB yang mengadopsi SDGs akan bekerjasama secara 
erat dengan pemerintah regional dan daerah; dan gugus tugas di tingkat daerah telah mengajukan berbagai usulan substansial yang termaktub dalam dokumen SDGs (Hoelman, Parhusip, Eko, Bahagijo, \& Santono, 2016).

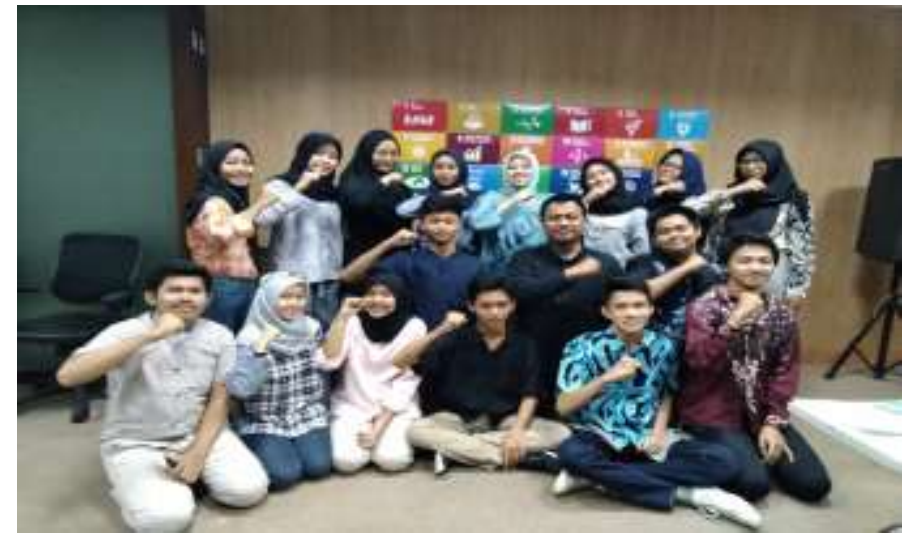

Gambar 1. Pemaparan SDGs Tujuan ke-11

Memasuki sesi kedua, para peserta diminta untuk memahami terlebih dahulu targettarget yang telah dijelaskan sebelumnya. Mereka akan menggunakan target-target tersebut sebagai modal untuk menilai kelebihan apa saja yang telah ada di Tangsel. Untuk memfokuskan proses capacity building, para peserta dibagi ke dalam tiga kelompok. Setiap kelompok diminta untuk berdiskusi tentang kelebihan kota tangsel dan hal-hal yang membuat mereka merasa nyaman. Dari hasil diskusi kelompok, disimpulkan ada tiga alasan terbesar mengapa Tangsel layak dan nyaman dihuni. Pertama, fasilitas umum yang memadai dimana telah terdapat banyak prasarana dan sarana penunjang kehidupan kota, seperti: rumah sakit yang berkualitas, baik miliki pemerintah maupun swasta; sekolah yang berkualitas; tempat hiburan yang ramah keluarga; dan sebagainya. Mereka berpendapat keberadaan fasilitas-fasilitas ini membuat warga Tangsel tidak perlu mencari fasilitas umum ke Jakarta. Kedua, moda transportasi umum yang variatif mulai dari angkot, bus, dan kereta api dengan pilihan jalan raya yang memadai sehingga memudahkan akses warga dari satu tempat ke tempat lainnya. Ketiga, ragam kebijakan fasilitas pemerintah yang pro warga, seperti: pembebasan Pajak Bumi dan Bangunan (PBB) yang Nilai Jual Objek Pajak (NJOP) di bawah 200.000.000 untuk tahun 2018 dan 2019; pemberian fasilitas layanan Rumah Sakit Umum Daerah (RSUD) secara gratis, dan sebagainya.

Pada sesi ketiga, setiap kelompok diminta untuk menjelaskan masalah-masalah atau kekurangan yang dihadapi oleh Tangsel. Kekurangan-kekurangan ini ditulis secara umum dilihat dari permasalahan yang ada di kota secara keseluruhan. Dari hasil diskusi, terdapat tiga masalah dasar yang harus segera diatasi oleh Pemkot. Pertama, masalah kebersihan yang terdiri dari dua isu, yakni sampah dan air bersih. Penanganan kebersihan di Tangsel masih belum terlaksana dengan baik mengingat kondisi lokasi Tempat Pembuangan Akhir (TPA) di Cipeucang yang sudah tidak lagi memadai. Sementara itu, ketersediaan air bersih juga menjadi permasalahan tersendiri untuk warga. Hal ini dikarenakan belum adanya pusat pengolahan air bersih yang dimiliki oleh Pemkot. Fasilitas pengelolaan air bersih untuk saat ini baru dimiliki oleh pengembang swasta. Kedua, pembangunan yang belum merata terutama di Kecamatan Setu yang relatif paling jauh jika ditinjau dari Jakarta. Kecamatan Setu sendiri memiliki potensi dengan keberadaan Pusat Pengkajian Ilmu dan Teknologi (Puspitek), Badan Tenaga Nuklir Nasional (BATAN) dan Institut Teknologi Indonesia (ITI). Belum lagi dengan semakin padatnya wilayah Tangsel sehingga para pekerja yang hendak mencari hunian terjangkau sudah mulai melirik wilayah Setu. Namun Pemkot juga perlu mempertimbangkan persoalan fasilitas umum dan akses transportasi yang masih belum memadai, ketimbang enam kecamatan lainnya. Ketiga, persoalan identitas kota yang tidak jelas. Hal ini menandakan bahwa secara sosial-budaya, Tangsel tidak memiliki suatu 
keunikan tertentu yang menjadi identitas kota. Masalah ini dianggap penting oleh peserta karena seringkali menghadirkan tanda tanya untuk mereka ketika ditanya asal muasal budayanya.

Terakhir, pada sesi keempat setiap kelompok diminta untuk memberikan solusi atas permasalahan yang ada. Selain itu, setiap kelompok juga diminta membuat program yang bisa dilakukan untuk mendukung solusi tersebut. Agar jangan sampai solusi yang ada hanya sebatas wacana tanpa adanya upaya menyelesaikannya secara nyata. Program yang dibuat dan dilaksanakan oleh Fatangsel juga menjadi indikator keberhasilan dari program capacity building yang dilaksanakan. Kelompok pertama berusaha menawarkan solusi kebersihan yang difokuskan pada sampah. Salah satu langkah yang bisa dilakukan guna mengurangi beban TPA Cipeucang adalah dengan melakukan pengelolaan sampah dengan baik dan tepat guna. Salah satu bentuknya adalah dengan melakukan pemilahan sampah agar mudah dikelola. Nantinya sampah yang akan masuk ke TPA Cipeucang hanya yang tidak lagi bisa diolah. Sebagaimana yang terdapat pada target ke-6 poin ke-11 SDGs. Dinas Lingkungan Hidup (DLH) Tangsel mencatat bahwa jumlah sampah yang dihasilkan warga mencapai 970 ton per hari. Sebanyak 250 ton dibuang ke TPA Cipeucang, sedangkan sisanya dikelola pihak swasta (Hambali, 2019). Selain itu, apabila TPA Cipeucang terus dijadikan satu-satunya tempat penimbunan sampah, maka dapat membawa dampak negatif bagi lingkungan, seperti: bau yang tidak nyaman hingga beberapa kilometer dari lokasi dan rembesan air lindi (sampah) yang bisa mencemari sungai Cisadane sebagai sumber air utama wilayah Tangerang Raya (Hambali, 2019).

Untuk mengatasi masalah ini, kelompok pertama hendak menyelenggarakan sosialisasi kesadaran warga untuk memilah sampah yang dihasilkannya. Salah satu sarana yang bisa dilakukan agar menghindari penumpukkan sampah adalah dengan melakukan pemilihan sampak sejak dibuang oleh pengguna. Hal ini akan memudahkan proses seleksi sampah. Selain itu, dengan melakukan pemilihan, sampah yang dapat digunakan untuk daur ulang tidak akan rusak akibat bercampur dengan sampah lain atau karena terkena air. Tetapi, kebanyakan warga di tangsel hanya memahami bahwa pemilahan sampah hanya terbagi ke dalam dua kategori: organik dan non-organik. Hal ini disebabkan oleh adanya program fasilitas tempat sampah yang disediakan Pemkot Tangsel meliputi dua kategori tersebut. Padahal saat ini pemilahan sampah telah terbagi ke dalam empat kategori, yaitu: (i) sampah organik yang nantinya bisa diolah menjadi pupuk kompos; (ii) sampah non-organik berupa plastik; (iii) sampah bahan berbahaya dan beracun (B3), seperti: kaca (beling), botol bekas obat kimia, deterjen, dan semacamnya; dan (iv) sampah kertas untuk didaur ulang menjadi kerajinan tertentu. Oleh karenanya sosisalisi yang dilakukan akan fokus pada pembagian sampah ke dalam empat kategori tersebut. Setelah itu, Fatangsel akan mengajak warga bersama untuk mengumpulkan sampah di lokasi yang telah ditentukan untuk kemudian dimasukkan ke dalam tempat sampah yang telah disediakan sesuai dengan kategori sampah.

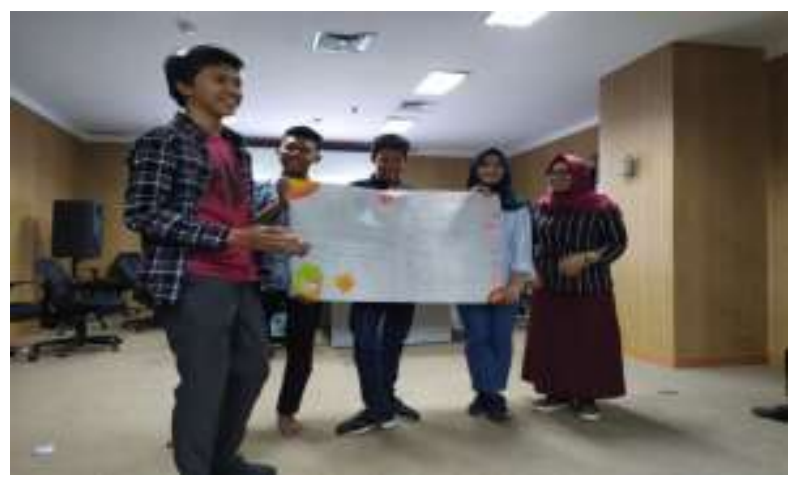

Gambar 2. Presentasi Kelompok 1

Kelompok kedua berusaha menawarkan solusi dengan membentuk komunitas ramah lingkungan sebagaimana yang terdapat pada target ke-7, yakni menyediakan akses inklusif untuk melindungi ruang hijau dan publik. Hal ini dimaksudkan agar warga, khususnya yang tidak tinggal 
di lingkungan yang dikelola pengembang swasta, dapat berpartisipasi dalam melestarikan hunian tinggalnya agar nyaman ditempati dan ramah anak. Komunitas ramah lingkungan ini dilakukan dengan mensosialisasikan lingkungan hidroponik. Nantinya di setiap Rukun Tetangga (RT) di Tangsel harus memiliki tempat untuk menanam hidroponik yang dimaksudkan untuk menghijaukan lingkungan. Selain itu, hasil tanaman hidroponik tersebut juga dapat dimanfaatkan untuk kebutuhan warga, terutama ketika menggelar acara bersama. Sosialisasi akan dilaksanakan di dekat Pemkot Tangsel yang memiliki gang-gang yang terkesan gersang. Setelah melaksanakan sosialisasi mengenai manfaat hidroponik bagi kelestarian lingkungan, Fatangsel akan mempraktikkan cara sederhana membuat perangkat hidroponik sekaligus menanam benih agar dalam waktu beberapa pekan ke depan sudah dapat tumbuh sebagai salah satu variabel keberhasilan sosialisasi dan program capacity building.

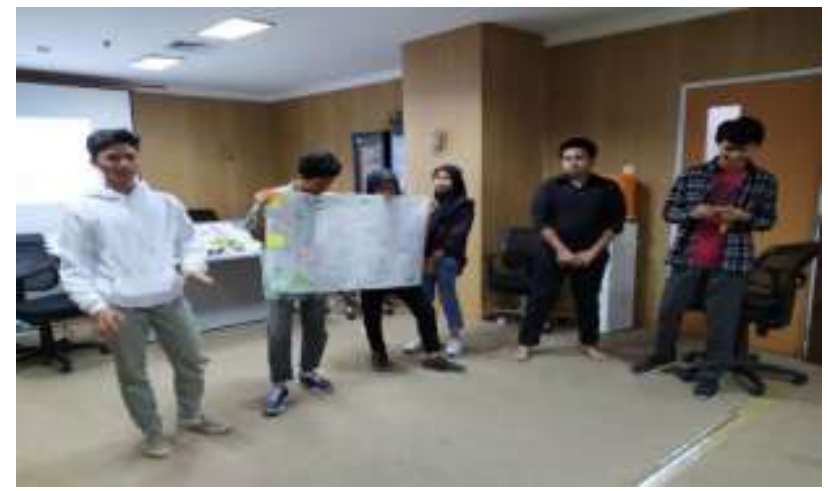

Gambar 3. Presentasi Kelompok 2

Sementara kelompok ketiga memilih untuk memenuhi target ke-4 mengenai perlindungan atas warisan budaya dan alam di Kota Tangsel. Kelompok ini berpendapat bahwa di Tangsel sebenarnya ada warisan sosial budaya yang selama ini tidak terlalu diketahui oleh banyak warganya. Untuk itu, Tangsel sebenarnya memiliki sejarah yang panjang, kendatipun saat itu masih termasuk ke dalam wilayah Tangerang Raya. Selain itu, Tangsel selama ini identik dengan wilayah sub-urban dari ibukota Jakarta. Hasilnya, sebagai besar warga Tangsel merupakan pekerja di ibukota dan kurang antusias dalam mengenal lebih jauh kotanya. Oleh karena itu, diperlukan adanya perbaikan terhadap situs-situs sejarah yang ada di Tangsel. Perbaikan ini wajib diikuti oleh adanya informasi yang mudah diakses oleh warga terkait keberadaan situs-situs tersebut. Adapun program yang ditawarkan oleh kelompok ketiga adalah napak tilas Tangsel dan mendengarkan penjelasan mengenai arti penting Tangsel di masa lalu. Kegiatan ini akan dipusatkan di Monumen Palagan Lengkong, Serpong. Monumen ini adalah simbol atas perjuangan Mayor Daan Mogot dan pasukannya dalam melucuti senjata Jepang agar tidak jatuh ke tangan Belanda. Namun sayang, tidak banyak warga Tangsel yang mengetahui lokasi ini. Untuk itu, program ini diadakan oleh Fatangsel agar warga, khususnya anak-anak dan pemuda yang tinggal di Tangsel bisa mengenal sejarah kotanya lebih dalam.

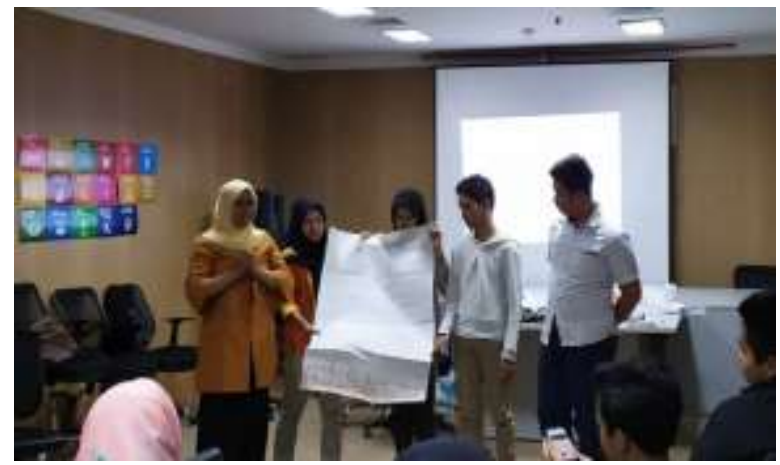

Gambar 4. Presentasi Kelompok 3 
Dari ketiga solusi dan program yang diajukan, Fatangsel memutuskan untuk melaksanakan kegiatan "World's Clean Day" yang diadakan pada 29 September 2019 pukul 08.00 - 11.00 WIB di Taman Kota 1, Serpong, Tangsel. Kegiatan ini bertujuan untuk mensosialisasikan kepada masyarakat yang hadir untuk bisa memilah sampah yang dihasilkannya. Adapun pemilihan Taman Kota 1 sebagai lokasi sosialisasi mengingat ramainya warga Tangsel yang hadir untuk berolahraga atau sekedar rekreasi bersama keluarga. Dalam kegiatan ini terdapat empat aktivitas yang dilakukan oleh Fatangsel. Pertama, melakukan olahraga bersama sebagai pemanasan sebelum melaksanakan sosialisasi. Kedua, melakukan sosialisasi tentang pentingnya pengelolaan dan pengolahan sampah untuk mewujudkan pembangunan komunitas dan kota berkelanjutan. Pada saat melakukan sosialisasi tentang SDGs masih banyak warga yang belum tahu dan paham tentang program tersebut. Di antara mereka juga belum memahami konsep pembangunan komunitas dan kota berkelanjutan. Hal ini menandakan adanya permasalahan terkait sosialisasi SDGs kepada warga yang dilakukan oleh pemerintah, baik di tingkat pusat maupun daerah. Selama ini banyak warga yang hanya mengetahui hal-hal praktis tentang bagaimana mewujudkan kota yang nyaman untuk ditinggali, seperti dalam hal kebersihan, kemudahan transportasi, pelayanan fasilitas umum, dan sebagainya, tetapi tidak dalam bentuk yang holistik. Oleh karenanya sosialisasi SDGs dapat membuka pemahaman warga tentang pentingnya menjaga kota agar tetap lestari sebagaimana yang termaktub dalam $7+3$ target di tujuan ke-11. Ketiga, membagi anggota Fatangsel ke dalam empat tim untuk membedakan jenis sampah yang akan diambil. Masing-masing tim mengajak masyarakat yang hadir untuk melakukan operasi semut untuk mengumpulkan dan memilah sampah yang baik dan benar. Setelah sampah-sampah dikumpulkan oleh setiap kelompok, Fatangsel menunjukkan empat jenis tempat sampah yang dibedakan atas dasar warna, yakni: hijau (organik), kuning (non-organik), merah (B3), dan biru (kertas). Setelah diberikan penjelasan mengenai kegunaan tempat sampah yang berbeda, setiap tim memasukkan sampah tersebut ke dalamnya. Keempat, sebagai aktivitas terakhir, Fatangsel menggelar kegiatan mewarnai gypsum gratis untuk anak-anak sekaligus mempromosikan lembaga tersebut.

Dalam pelaksanakan program implementasi ini, terdapat beberapa tantangan yang dihadapi. Pertama, ketersediaan tempat sampah 4 warna yang masih terbatas. Padahal, di tempat umum layaknya Taman Kota 1 diperlukan banyak tempat sampah untuk memudahkan pengunjung. Kedua, di tempat sampah belum memiliki keterangan jelas terkait perbedaan warna yang ada. Selain itu, belum ada sosialisasi tertulis mengenai kegunaan tempat sampah warna dan manfaatnya bagi warga. Ketiga, tenaga kebersihan yang terbatas sehingga menyebabkan terjadinya penumpukan sampah di beberapa titik. Terkait tantangan pertama dan kedua, Pemkot dapat menggunakan dana Corporate Social Responsibilty (CSR) perusahaan-perusahaan yang beroperasi di Tangsel untuk memberikan fasilitas tersebut. Sementara untuk tantangan ketiga, apabila jumlah tempat sampah telah ditingkatkan disertai dengan sosialisasi yang jelas, maka tenaga kebersihan sebenarnya dapat diminimalisir. Namun membangun kesadaran masyarakat memang sulit mengingat adanya kebiasaan membuang sampah yang telah menjadi budaya diri.

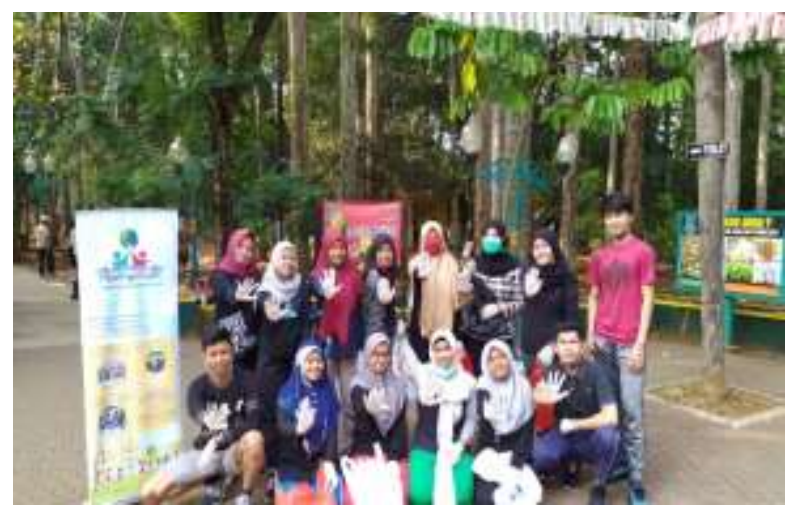

Gambar 5. Implementasi Program di Taman Kota 1 Bumi Serpong Damai 


\section{KESIMPULAN}

Dari kegiatan PkM yang penulis lakukan, kami menemukan fakta bahwa pemahaman masyarakat, khususnya dalam komunitas Fatangsel, masih terbatas. Sebagian mereka memang telah mendengar SDGs, tetapi belum mengetahui secara mendasar maksud dan tujuan-tujuan apa saja yang terdapat di dalamnya. Hal inilah yang menyebabkan penulis hendak mensosialisasikan persoalan SDGs kepada mereka, terutama yang menyangkut persoalan pembangunan kota dan komunitas berkelanjutan sebagaimana yang terdapat dalam tujuan kesebelas. Penulis mencoba memberikan pengetahuan dan pemahaman kepada Fatangsel dalam bentuk peningkatan kapasitas agar mereka dapat lebih aktif terlibat dalam kegiatan sekaligus menstimulus mereka untuk turut berpartisipasi dalam merealisasikan tujuan tersebut. Dengan menggunakan metode peningkatan kapasitas, penulis juga bermaksud mengarahkan peserta dalam merumuskan program sederhana untuk turut berkontribusi bagi pembangunan kota dan komunitas berkelanjutan.

Namun perlu dicatat bahwa metode ini hanya bisa dilakukan jika peserta mengetahui dengan baik objek yang dibahas, yakni Kota Tangsel. Jika tidak, maka akan membuat pelatihan ini kurang maksimal karena penilaian atas permasalahan yang ada dan solusi untuk mengatasinya hanya akan berbasiskan asumsi lepas tanpa diikuti oleh empirisme yang kuat. Selain itu, peserta yang hadir diharapkan merupakan representasi proporsional dari kecamatan-kecamatan atau bahkan kelurahan-kelurahan yang ada di kota tersebut. Tujuannya adalah agar penilaian permasalahan kota menjadi lebih komprehensif.

Di masa depan, diharapkan kegiatan ini dapat melibatkan Pemkot secara langsung agar hasil pelatihan dan solusi yang ditawarkan oleh peserta dapat menjadi bahan rekomendasi kebijakan pemerintah. Selain itu, keberadaan Pemkot diharapkan dapat memberikan dukungan dana terhadap kegiatan yang dilakukan. Tujuannya adalah agar semua solusi yang ditawarkan oleh peserta dapat diimplementasikan secara nyata.

\section{UCAPAN TERIMA KASIH}

Penulis mengucapkan terima kasih kepada Lembaga Penelitian dan Pengabdian Masyarakat (LPPM) Universitas Pembangunan Nasional "Veteran" Jakarta (UPNVJ) yang telah mendukung kegiatan ini melalui pemberian dana hibah internal periode 2019.

\section{DAFTAR PUSTAKA}

Ardiansah, \& Andrizal. (2019). Penyelenggaraan Pelayanan Publik Berdasarkan UndangUndang Tentang Pelayanan Publik Di Kecamatan Mempura Kabupaten Siak. Dinamisia: Jurnal Pengabdian Kepada Masyarakat, 3(2), 368-377. https://doi.org/10.31849/dinamisia.v3i2.3493

Badan Perencanaan Pembangunan Nasional. (2017). Metadata Indikator Tujuan Pembangunan Berkelanjutan (TPB)/Sustainable Development Goals (SDGs) Indonesia: Pilar Pembangunan Lingkungan. Jakarta: Bappenas.

Connolly, P., \& York, P. (2002). Evaluating Capacity-Building Efforts for Nonprofit Organizations. Organization Development Practitioner, 34(4), 33-39. Retrieved from http://www.aapcho.org/wp/wp-content/uploads/2014/02/per_art_evaluating.pdf

Hambali. (2019). TPA Cipeucang Tangerang Selatan dinilai Bahayakan Manusia dan Lingkungan. $\quad$ Retrieved July 18, 2019, from https://news.okezone.com/read/2019/02/28/340/2024059/tpa-cipeucang-tangerangselatan-dinilai-bahayakan-manusia-dan-lingkungan

Hoelman, M. B., Parhusip, B. T. P., Eko, S., Bahagijo, S., \& Santono, H. (2016). Sustainable Development Goals-SDGs: Panduan untuk Pemerintah Daerah (Kota dan Kabupaten) dan Pemangku Kepentingan Daerah. Sustainable Development. Jakarta: INFID. Retrieved from 
https://www.infid.org/wp-content/uploads/2018/07/Buku-Panduan-SDGs-untukPemda.pdf

Juliawanti, L. (2018). Survei: Hore! Tangerang Selatan Jadi Kota Paling Layak Huni di Indonesia. Retrieved March 20, 2019, from https://www.idntimes.com/news/indonesia/linda/survei-tangerang-selatan-jadi-kotapaling-layak-huni-di-indonesia-1/full

Lammert, J. D., Johnson, L., \& Fiore, T. A. (2015). Conceptualizing Capacity Building. Retrieved February 20, 2019, from https://www2.ed.gov/about/offices/list/osers/osep/rda/cipp2conceptualizing-capacity-building-2-10-15.pdf

Putri, L. D. (2017). Pelatihan Perencanaan Partisipatif Dalam Penataan Kawasan Kumuh Meranti Kota Pekanbaru. Dinamisia : Jurnal Pengabdian Kepada Masyarakat, 1(1), 129-137. https://doi.org/10.31849/dinamisia.v1i1.427

Ratnasari, J. D., Makmur, M., \& Ribawanto, H. (2013). Pengembangan Kapasitas (Capacity Building) Kelembagaan Pada Badan Kepegawaian Daerah Kabupaten Malang. Jurnal Administrasi Publik Mahasiswa Universitas Brawijaya, 1(3), 103-110.

Sachs, J. D. (2012). From millennium development goals to sustainable development goals. The Lancet, 379(9832), 2206-2211. https://doi.org/10.1016/S0140-6736(12)60685-0

United Nations. (1973). Report of the United Nations Conference on the Human Environment. United Nations. New York: United Nations. https://doi.org/10.1080/00103829.1973.10877486

Wing, K. T. (2004). Assessing the Effectiveness of Capacity-Building Initiatives: Seven Issues for the Field. Nonprofit and Voluntary Sector Quarterly, 33(1), 153-160. https://doi.org/10.1177/0899764003261518 